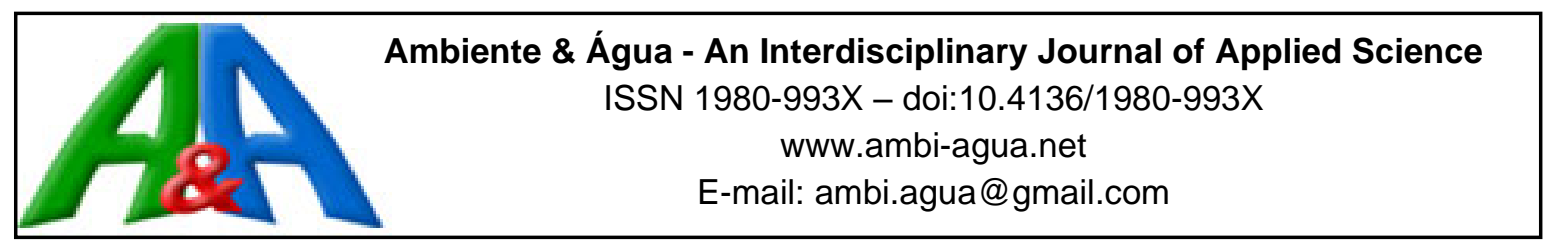

\title{
Stemflow and throughfall in agricultural crops: a synthesis
}

\author{
ARTICLES doi:10.4136/ambi-agua.2528
}

Received: 05 Feb. 2020; Accepted: 24 Nov. 2020

\author{
Valdemir Antoneli ${ }^{1 *}$; Fabio Caian de Jesus ${ }^{1}$; \\ João Anésio Bednarzi ${ }^{1}$; Edivaldo Lopes Thomaz ${ }^{2}$ iD \\ ${ }^{1}$ Departamento de Geografia. Universidade Estadual do Centro-Oeste (Unicentro), Rua Professora Maria Roza \\ Zanon de Almeida, s/n, CEP: 84505-677, Campus de Irati, Irati, PR, Brazil. \\ E-mail: fabiocaian.geografia@gmail.com,joaogeo2013@gmail.com \\ ${ }^{2}$ Departamento de Geografia. Universidade Estadual do Centro-Oeste (Unicentro), Alameda Élio Antonio Dalla \\ Vecchia, nº 838, CEP: 85040-167, Campus Cedeteg, Guarapuava, PR, Brazil. \\ E-mail: thomaz@unicentro.br \\ *Corresponding author. E-mail: vaantoneli@gmail.com
}

\begin{abstract}
The interception of rainwater in annual and perennial agriculture has been the object of several studies in the last decades. However, scant attention has been paid to where this research has taken place and which principal crops have been studied. The objective of this research is to perform a bibliometric analysis of one hundred articles from the last forty years found in the Scopus database to analyze their spatial distribution according to continent and country and quantify the research carried out on annual and perennial crops. Also, the main methods used to investigate the stemflow and throughfall of water in commercial crops are described. Our analysis indicates that the northern hemisphere has the most research on the subject and 35\% of the research took place in Asia. Most of the research into annual crops (56\%) was carried out in maize (Zea mays L.). There has been a significant increase in commercial (annual) agricultural research in the last decade. The stemflow had the most amplitude between the values in the annual crops. This may be related to morphological and ecophysiological changes throughout the plant cycle. For perennial crops, stemflow values were like forests. It has become more important than ever to consider a scenario of global climate change stemflow and throughfall research in agricultural areas, or at least the data need to be revised in the face of new climatic conditions.
\end{abstract}

Keywords: annual crop, bibliometric analysis, interception, perennial crop.

\section{Fluxo de tronco e atravessamento de água em culturas agrícolas: uma síntese}

\section{RESUMO}

O atravessamento da água da chuva em agriculta (temporária e perene), têm se tornado objeto de diversos estudos nas últimas décadas. Entretanto, pouca atenção tem se dado para identificar onde essas pesquisas têm sido desenvolvidas e quais as principais culturas têm sido pesquisadas. O objetivo dessa pesquisa é realizar uma análise bibliométrica de 100 artigos dos últimos 40 anos encontrados na base de dados Scopus para analisar a distribuição espacial dos estudos de acordo com continente e países; quantificar as pesquisas realizadas em culturas temporárias e perenes; descrever os principais métodos utilizados na investigação do stemflow 
e throughfall da água em culturas comerciais. Ao término dessa pesquisa observamos que o hemisfério norte indicou o maior número de pesquisas sobre o tema e $35 \%$ das pesquisas foram desenvolvidas na Ásia. A maior parte das pesquisas em cultura temporária $(56,1 \%)$ foram realizadas no cultivo de milho (Zea mays $L$.). Houve aumento significativo das pesquisas na agricultura comercial (temporária) na última década. O stemflow indicou maior amplitude entre os valores nas culturas temporárias. Esta condição pode estar relacionada a mudança morfológicas e ecofisiológicas ao longo do ciclo da planta. Já nas culturas perene os valores de stemflow foram similares as florestas. Considerando um cenário de mudanças climáticas, os resultados das pesquisas sobre atravessamento e fluxo de tronco em áreas agrícolas tornou-se mais importante do que nunca, ou pelo menos os dados precisam ser revisados diante de novas condições climáticas.

Palavras-chave: análise bibliométrica, atravessamento, cultura anual, cultura perene.

\section{INTRODUCTION}

Vegetation plays a fundamental role in the hydrological dynamics of a given area, being responsible for the first portioning of rainwater (Togashi et al., 2012). When water reaches the vegetation canopy, a part is intercepted and evaporated during and after the rainfall (Fan et al., 2014). The water that crosses the vegetation is redistributed and reaches the ground through interception, which consists of throughfall (dripping from the canopy and free interception) and stemflow (Germer, 2013; Van Stam and Gordon, 2018).

Rainwater interception varies greatly among climatic regions, as it depends on factors such as vegetation characteristics (Herwitz, 1985), meteorological conditions (Andre et al., 2008), rainfall characteristics (Yuan and Gao, 2016), and the three-dimensional geometry of the canopy structure (Bialkowski and Buttle, 2015), among others.

There is a considerable range of research in the literature that focuses on hydrological dynamics in forests with an emphasis on stemflow and throughfall (Germer, 2013, Liang et al., 2011, Zhang et al., 2017). These data are required to calculate water availability in river watersheds (Czikowsky and Fitzjarrald, 2009).

"Stemflow" means all water and solute that reaches the soil through the stem of the plant (Zhao et al., 2020). The volume of water that reaches the soil through the stemflow varies from 5 to $10 \%$ (Levia Jr. and Frost, 2006) and affects only the soil portion located close to the trunk (Brecciaroli et al., 2012). "Throughfall" is the fraction of rain that reaches vegetation soil through the canopy of vegetation, which can occur through free fall (open places in the canopy of the plant) or through the dripping of leaves (Levia Jr. and Frost, 2006; Gasparoto et al., 2014). However, throughfall has received more attention than stemflow because of the scarce hydrological significance of the latter (Tobón Marin et al., 2000).

In spite of the extensive discussion about the influence of vegetation on the stemflow and throughfall in the most diverse forest fragments, little attention has been given to research that evaluates the stemflow and throughfall in different crops in the agricultural landscape.

Understanding the stemflow and throughfall in different crops is an essential tool for several studies: (Frasson and Krajewski, 2011), for instance, soil moisture distribution (Hornbuckle et al., 2008), soil erosion management (Bui and Box, 1992), and irrigation control (Steiner et al., 1983), among others. However, some issues have been neglected, such as the main types of crop used to analyze hydrological dynamics and how each crop responds to the process of rainwater interception.

Therefore, this review aims to inventory the research carried out in stemflow and throughfall of rainwater in agricultural areas. In addition, there is specific focus on: a) the spatial distribution of the studies according to continent and country; b) quantifying the research 
carried out on perennial and annual crops; c) describing the main methods used to investigate stemflow and throughfall in commercial crops; and d) a critical evaluation of the results obtained over forty years of research, in the face of the current challenges of global climate change and research needs as well.

\section{MATERIALS AND METHODS}

To carry out this research, the Scopus database was used to identify research related to the themes of throughfall and stemflow in different types of annual and perennial crops. It is important to note that annual crops are those with a short seasonal cycle, which are replanted every year. Perennial or semi perennial, e.g., sugar cane crops do not require yearly planting and are usually assigned a minimum duration of four years.

The database search field identified articles containing the words " throughfall and stemflow" in the titles, keywords, and abstracts. A bibliometric analysis was carried out with 100 articles (all in English) about the stemflow and throughfall in agriculture. The goal of the study was not to search for all available studies. Instead, research articles from the last forty years were selected.

Only research results referring to stemflow and throughfall in annual and perennial agriculture were included. Therefore, the measurement period (annual or seasonal values), monitoring length and number of events measured were not considered. Moreover, articles that did not measure stemflow and throughfall at the same time were considered. Some articles in annual crops did not measure the stemflow; however they indicated a value below $5 \%$. The articles used in perennial crops were classified into monoculture and agroforestry. The method for obtaining stemflow and throughfall data was separated. Most articles used direct measurement to collect data in the field and other articles used modeling to obtain data. The second case was considered in the present study.

The data were organized based on the frequency of the subjects researched and grouped by type of crops. The articles were classified as: a) perennial crops, such as coffee (Coffea), sugar cane (Saccharum officinarum), cocoa (Theobroma cacao), rubber tree (Hevea brasiliensis), citrus (Citrus X sinensis), apple (Malus domestica), banana (Musa acuminate), palm (Bactris gasipaes), olive (Olea europaea), grapes (Vitis vinifera L.), pomegranate (Punica granatum), clove (Syzygium aromaticum), cassava (Manihot esculenta), cashew (Anacardium occidentale) and nut tree (Bertholletia excels); and, b) annual crops: corn (Zea mays), soybean (Glycine max), wheat (Triticum), potato (Solanum tuberosum), cotton (Gossypium), rapeseed (Brassica napus), brussels sprouts (Brassica oleracea var. gemmifera), millet (Pennisetum glaucum), beet (beta. L), alfalfa (Medicago sativa L.) and sorghum (Sorghum bicolor). All the data collected were spatialized worldwide to understand where the studies had been conducted and which are the most prominent regions.

\section{RESULTS}

\subsection{The spatialization of research on stemflow and throughfall in different crops and its evolution in the last decades}

Studies on the stemflow and throughfall in different crops (annual and perennial) have been frequent in recent decades. However, the vast majority are concentrated in a small number of countries. About $70 \%$ of the surveys were conducted in temperate regions and only $30 \%$ in tropical areas. In temperate regions, research on annual crops predominates, whereas in tropical areas, research on perennial crops is more frequent (Figure 1).

Among the articles analyzed, $43 \%$ refer to the stemflow and throughfall in perennial crops and $57 \%$ in annual crops. Of this total, 35\% are in Asia, 22\% in North America, $18 \%$ in Europe, $14 \%$ in South America, 5\% in Central America, 4\% in Africa and 2\% in Oceania. 


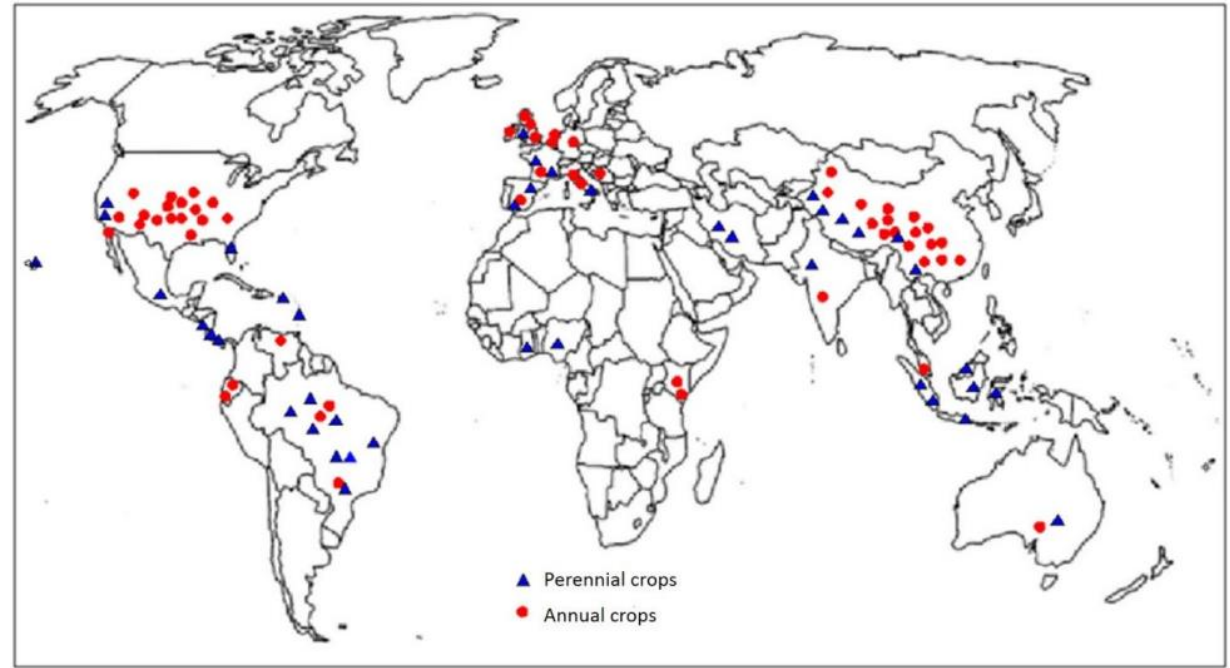

Figure 1. Distribution of research on stemflow and throughfall.

Source: Based on Van Stan and Gordon (2018).

In Asia, $67 \%$ of the research was carried out in China and $17 \%$ in Indonesia. In Europe, there is a wider distribution of studies across countries. Among the 18 papers registered on the continent, $23 \%$ (4 surveys) were conducted in the United Kingdom. Spain, Italy, and France account for $16 \%$ each (three surveys in each country). There were 22 surveys in North America, of which 21 (95\%) were in the United States. In South America, 14 surveys were found; 78\% of these were carried out in Brazil. Central America, Africa, and Oceania had the smallest number of studies (five, four and two, respectively) (Figure 2).

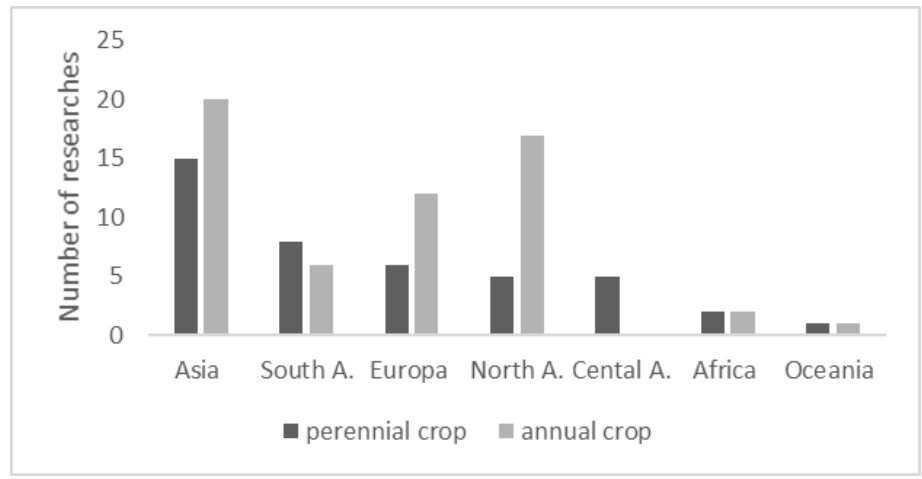

Figure 2. The amount of research into annual and perennial crops in each continent.

Most of the research on stemflow and throughfall in Asia, Europe, and North America involved annual crops (Figure 1). The biggest difference was in North America, where $77 \%$ of the research was carried out on annual crops. In Central America, five studies were identified, which all dealt with perennial crops. Countries such as Indonesia and Brazil had the highest percentage of research into perennial cultivation (100\% and $73 \%$, respectively).

An analysis of the evolution of research on the subject over the last forty years (1979 to 2019) evidences some intensification in the last decade (Table 1), mainly regarding annual crops. Among the studies completed during the analyzed period, $48 \%$ were from the decade of 2010.

Between the decades of 1980 and 2000, research into perennial crops was noteworthy; there were 34 studies in that period. On the other hand, in the same period, only 18 studies on annual crops were found. In the last decade, there was a $150 \%$ increase in research of annual crops, while for perennial crops the increase was $35 \%$. 
Table 1. Distribution of research in stemflow and throughfall in the last decades.

\begin{tabular}{|c|c|c|c|c|c|c|}
\hline \multirow{2}{*}{ Decades } & \multicolumn{2}{|c|}{ Perennial crop } & \multicolumn{2}{|l|}{ Annual crop } & \multirow{2}{*}{ Total studies } & \multirow{2}{*}{$(\%)$} \\
\hline & Number of studies & $(\%)$ & Number of studies & $(\%)$ & & \\
\hline 1980 & 9 & 15.7 & 3 & 7.0 & 12 & 12.0 \\
\hline 1990 & 8 & 14.0 & 5 & 11.6 & 13 & 13.0 \\
\hline 2000 & 17 & 29.8 & 10 & 23.3 & 27 & 27.0 \\
\hline 2010 & 23 & 40.3 & 25 & 58.1 & 48 & 48.0 \\
\hline Total & 57 & 100.0 & 43 & 100.0 & 100 & 100.0 \\
\hline
\end{tabular}

\subsection{Types of crops studied and their stemflow and throughfall rate}

Among all the research observed in annual crops, $56 \%$ was carried out on maize, followed by soybean at $12 \%$, and wheat and potato $7 \%$. Of the total research done on maize, $31 \%$ was developed in China (10 studies) and 28\% (9 studies) in the United States.

When analyzing the research into perennial crops, it is evident that there is a greater diversity of crops without one type predominating, unlike studies of annual crops. Plants such as coffee, rubber, cacao, and citrus had the highest percentages (11\% each).

The diversity of annual and perennial crops and their characteristics affect the stemflow and throughfall rate. The data found in perennial crops are similar to those observed in forests, due to the similarity of some species (Table 2). However, the data on annual crops show variations due to the structure and morphology of each species, mainly concerning the vegetative stage of the plant.

Table 2. Stemflow and throughfall rate in annual and perennial crops.

\begin{tabular}{|c|c|c|c|c|c|}
\hline Annual crops & Number of studies & Stemflow (\%) & Amplitude & Throughfall (\%) & Amplitude \\
\hline Corn & 32 & $11-49$ & 4.5 & $58-82$ & 1.4 \\
\hline Soybean & 7 & $3-23$ & 7.6 & $57-92$ & 1.6 \\
\hline Wheat & 4 & $3-20$ & 6.6 & $70-89$ & 1.3 \\
\hline Potato & 4 & $08-46$ & 2.3 & $54-70$ & 1.3 \\
\hline Cotton & 4 & $5-13$ & 2.6 & $62-81$ & 1.3 \\
\hline Rapeseed & 2 & $3-19$ & 6.3 & $40-65$ & 1.6 \\
\hline Brussels Sprout & 1 & $0.8-6$ & 7.5 & $71-98$ & 1.2 \\
\hline Millet & 1 & $10-19$ & 1.9 & $70-82$ & 1.1 \\
\hline Beet & 1 & $18-40$ & 2.2 & $56-70$ & 1.2 \\
\hline Alfalfa sprouts & 1 & $12-22$ & 1.8 & $65-80$ & 1.2 \\
\hline Sorghum & 1 & $5-19$ & 3.8 & $62-75$ & 1.2 \\
\hline Perennial crop: & Number of studies & Stemflow $(\%)$ & Amplitude & Throughfall (\%) & Amplitude \\
\hline Coffee* & 5 & $1-14$ & 14 & $50-90$ & 1.8 \\
\hline Rubber tree* & 5 & $1.1-9.2$ & 8.4 & $64-85$ & 1.3 \\
\hline Citrus & 5 & $0.5-4.7$ & 9.4 & $82-92$ & 1.1 \\
\hline Cocoa* & 5 & $0.2-9.1$ & 45 & $76-90$ & 1.2 \\
\hline Palm * & 5 & $5-16$ & 3.2 & $70-83$ & 1.1 \\
\hline Banana & 4 & $6-26$ & 1.4 & $61-74$ & 1.2 \\
\hline Apple & 3 & $0.8-10$ & 12.5 & $50-84$ & 1.7 \\
\hline Olive & 3 & $1.5-24$ & 16 & $56-70$ & 1.2 \\
\hline Sugar cane & 2 & $19-25$ & 1.3 & $31-58$ & 1.9 \\
\hline Grapes & 1 & $2-6$ & 3.0 & $65-85$ & 1.1 \\
\hline Pomegranate & 1 & $3-10$ & 3.3 & $71-80$ & 1.1 \\
\hline Clove & 1 & $0.9-5$ & 5.5 & $63-87$ & 1.3 \\
\hline Cassava & 1 & $0.5-4$ & 8.0 & $79-92$ & 1.1 \\
\hline Cashew & 1 & $1-3$ & 3.0 & $65-80$ & 1.2 \\
\hline Nut tree* & 1 & $1-5$ & 1.3 & $72-89$ & 1.2 \\
\hline
\end{tabular}

Note $^{1}$ : The rates indicated refer to the means extracted from the articles analyzed.

* Some studies used in this type of crop were carried out in agroforestry (see text below). 
The highest stemflow in annual crops were observed in soybean and wheat, with an amplitude of 6.6 and 7.6 respectively. However, potato and maize crops had the highest stemflow rates $(20-46 \%$ and $11-49 \%)$. Of the perennial crops, cocoa had the greatest amplitude (45), while banana and sugarcane cultivation indicated the highest stemflow values. The amplitude of the throughfall between the annual and perennial crops was similar. However, soybean had the highest variation among the annual crops (57-92\%). Coffee and sugar cane had the highest amplitudes (19 and 18 respectively). However, the highest throughfall values were observed in citrus crops (82-92\%).

Some types of perennial crops used in this research were developed in monoculture or agroforestry. Among the 43 studies on perennial cultivation used in this work, 10 (23.2\%) were carried out in agroforestry ( 2 studies on coffee crops, 2 on palms, 2 on rubber, 3 on cocoa and 1 on Nut trees).

\subsection{Stemflow and throughfall methods and models for data collection.}

Different approaches have been used to collect stemflow and throughfall data in agriculture, including modeling (Levia Jr. and Frost, 2003), and using simple or even automated equipment (Dunkerley, 2014). The characteristics of each crop, both annual and perennial, allowed these methods to be adapted in various ways. We emphasize that the measurement of throughfall and stemflow in different crops is a critical phase in understanding water availability in the soil, since an error in data collection may over- or sub-estimate the results.

A predominance of the spiral collector method $(65 \%)$ for measuring stemflow data from perennial and annual crops was noticed. The funnel method involving the non-spiral stem was used in $10 \%$ of the studies (Figure 3). It should be taken into consideration that this method was used in stems with a diameter $\leq 15 \mathrm{~cm}$, like sugarcane and coffee. Although modeling is not a primary method of data collection, $25 \%$ of selected articles used equations and models to estimate hydrological processes. It is important to note that some perennial crops species resemble native forests. In this case, some studies estimate stemflow to be less than $5 \%$ of the precipitation (Levia Jr. and Frost, 2003).

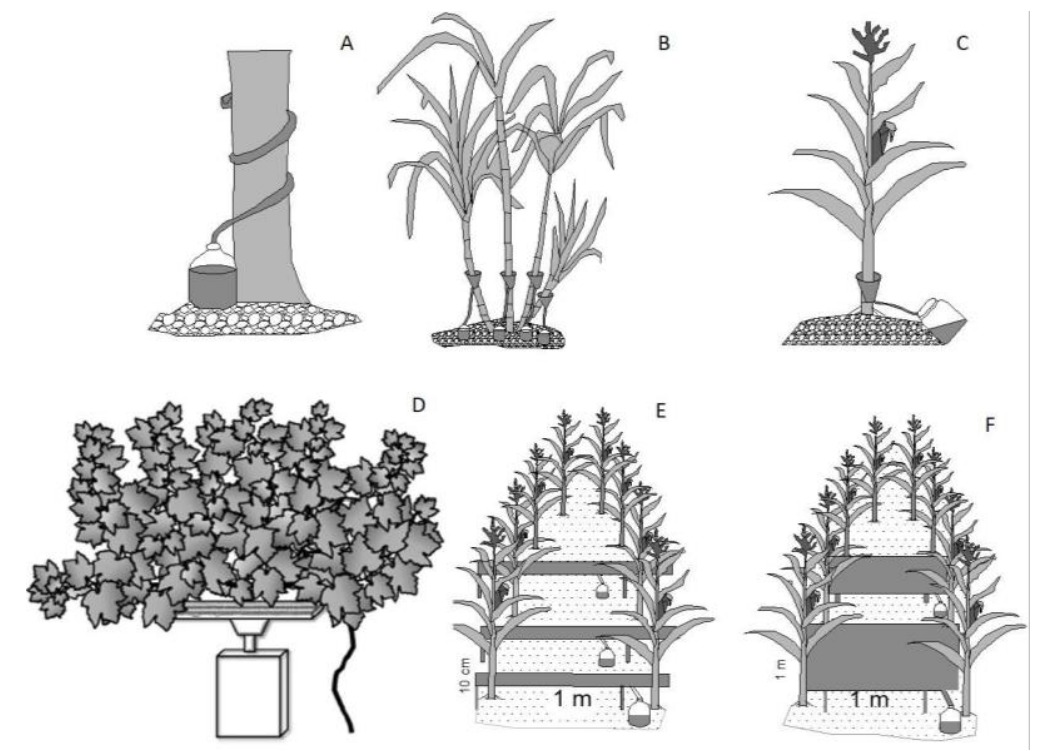

Figure 3. Different methods of stemflow and throughfall collection in perennial and annual crops.

Note: A and B) stemflow collector in perennial crops; C) stemflow collector in annual crops; D) throughfall collector in perennial crop; $\mathrm{E}$ and $\mathrm{F})$ throughfall collector in annual crops (E = 10x100 cm collectors; F) $100 \times 100 \mathrm{~cm}$ collectors). 
To measure throughfall, $70 \%$ of the research used funnel-type collectors, $20 \%$ used collecting gutters of different shapes and sizes, and $10 \%$ used equations and models, including the Rutter model (Rutter et al., 1971) and the Gash model (Gash, 1979). It is noteworthy that $86 \%$ of the surveys of perennial crops used natural rainfall, and only $14 \%$ used simulated rain. The simulation allows greater control of variables such as the intensity and duration of rainfall (Sousa Jr. et al., 2017), according to the objective of the study.

In annual crops, $53 \%$ of the studies were carried out with simulated rainfall, both in the field and in the laboratory, and $47 \%$ with natural rainfall. To measure the stemflow, $84 \%$ of the research used the funnel method on the plant stem, and 16\% used modeling.

\section{DISCUSSION}

The results of this inventory show that research on the stemflow and throughfall in agricultural areas is concentrated in the Northern Hemisphere. This trend may be due to commercial agriculture in this region having a longer history than other continents. Moreover, the tradition of scientific research and the production of physical-mathematical models for soil and water management in agricultural systems requires primary data. Despite the Brazilian agricultural expansion into different ecosystems, research on stemflow and throughfall is still incipient, especially in commercial crops. We believe that the reasons for this are varied: a focus on soil management to increase productivity; the belief that the no-tillage system serves a conservationist agriculture; the physical-mathematical models imported from other regions of the world are calibrated / applied without the need to produce primary data. Finally, agricultural research thinking on soil conservation is grounded in the Universal Soil Loss Equation, where the factor of vegetation cover is widespread and can, therefore, influence research on this subject (Barreto et al., 2009), among other possibilities. Therefore, there is an enormous deficit of studies in hydrological processes, particularly stemflow and throughfall, in the Brazilian territory.

Annual crops were the most researched in the last decade, as the extension of annual crops such as soybean, corn, and wheat, among others, is higher compared to perennial crops. This increase in research can be attributed to the growth in global demand for food in recent decades (FAO, 2019). Besides, its short cycle and the morphological and ecophysiological changes throughout its development implies variations in stemflow and throughfall according to the phases (Levia and Germer, 2015). Consequently, studies are intensified to represent stemflow and throughfall appropriately at each stage. Furthermore, for example, to monitor and model contaminant transfer processes in agricultural areas, the development phase of the crop is critical. On the other hand, in many cases, perennial crops have less morphological and ecophysiological changes when they reach maturity (e.g. coffee, rubber trees, olive trees, citrus trees, others). Perennial crops were the most studied in the past, and this should have been enough to provide reliable information for soil and water management, especially the throughfall. However, it is possible to verify the absence of studies in some agroforestry systems, e.g., yerba mate (Illex paraguariensis).

Despite the reasonable number of studies of both types of cultivation carried out worldwide, the variability in the hydrological processes measured is enormous (see Table 2). This variation is more considerable for stemflow than throughfall. Indeed, stemflow is significant in both annual and perennial crops. The hydrological processes in agricultural areas by this process should not be neglected. Therefore, soil and water conservation modeling, as well as studies of the transfer of contaminants in agricultural watersheds, may face difficulties because the data in the literature on this process is variable. Therefore, stemflow studies in different ecosystems, climates and agricultural crops are necessary.

Conversely, data on throughfall is more stable; that is, it shows less variability. It is interesting to note that the average minimum throughfall, $60 \%$ and $63 \%$, and the maximum, 
$80 \%$ and $82 \%$, are equivalent for annual and perennial crops, respectively. So, in hydrological terms, it is a mistake to think that a cotton or soybean plant, for example, intercepts less rain than orange or rubber trees.

Methods to measure stemflow and throughfall are not particularly varied or sophisticated, facilitating the standardization of measurement methods. In annual crops, it is more difficult to measure the stemflow, especially in species where the stem is not ligneous, such as: alfalfa sprouts, wheat, sorghum, beet, among others. However, there is extensive variation in this process. Annual crops are flexible in the use of rainfall simulators to measure stemflow and throughfall. The use of simulators means annual crops can be measured throughout their cycle, and it is possible to evaluate the effects of morphological and ecophysiological changes on hydrological processes. Meanwhile, perennial crops, especially the larger ones (i.e., height and canopy projection), are more dependent on natural rainfall measurements. Therefore, the methods are adjusted to the morphological and ecophysiological characteristics of the crops being evaluated.

Over the course of forty years of stemflow and throughfall studies, we observed several objectives, including understanding the hydrological process (Levia Jr. and Frost, 2003; Dugas, 1990); soil erosion (Zheng et al., 2019; Antoneli et al., 2018), soil water balance (Canone et al., 2017), the transfer of contaminants (Ranalli and Macalady, 2010), and others. However, in a scenario of global climate change (Pachauri et al., 2014), stemflow and throughfall research in agricultural areas has become more important than ever, or at least the data needs to be revised in the face of new climatic conditions. It is necessary to understand how crops, pastures, and agroforestry will respond hydrologically to climate change and how that will affect the water, nutrient and contaminant circulation in soils, hillslopes and watersheds.

Over the Brazilian territory, climate change may be different. For example, in southern Brazil, rainfall is expected to increase (PBMC, 2013), while in the Amazon region droughts may be prevalent (Marengo and Espinoza, 2016; Malhi et al., 2008). The Brazilian Panel on Climate Change (PBMC, 2013), estimates that the Brazilian territory may have: a) altered temperature and rain patterns; b) changes in annual rainfall patterns; c) increased plant growth and evapotranspiration; and d) increases in water deficit (droughts). Consequently, the migration of crops between edaphoclimatic zones may occur. Changes in climate allied to changes in land use, especially agricultural intensification, can affect hydrological processes, water quality and quantity, and ecosystem services in watersheds (Foley et al., 2005). Therefore, given these scenarios, studies on stemflow and throughfall in Brazilian agricultural landscape are needed, above all, with a perspective that goes beyond the simple vision of soil and water management.

\section{CONCLUSION}

Temperate regions indicated a higher number of studies (70\%), with a predominance of studies on annual crops. Only $30 \%$ of the studies were carried out in tropical regions, with a predominance on perennial crops. The USA and China carried out the largest number of studies on annual crops. This trend may be due to commercial agriculture and a greater incentive in researching primary data to develop equations and models.

The stemflow shows the greatest variation compared to throughfall. This hydrological process in agricultural areas cannot be neglected, especially when using modeling to quantify the variables that interfere with hydrological processes in watersheds.

Most of the research on throughfall and stemflow in annual crops were carried out through rain simulation. In perennial crops, data were collected with natural rain.

In annual crops, it is necessary to make several measurements along the cultivation cycle, as each plant phase can respond differently to hydrological processes. 


\section{REFERENCES}

ANDRE, F.; JONARD, M.; PONETTE, Q. Influence of species and rain event characteristics on stemflow volume in a temperate mixed oak-beech stand. Hydrological. Process, $n$. 22, p. 4455-4466, 2008. https://doi.org/10.1002/hyp.7048

ANTONELI, V. LENATORVICZ, H.H.; BEDNARZ, J.A.; PULIDO-FERNÁNDEZ, M.; BREVIK, E.C.; CERDÀ, A.; RODRIGO-COMINO, J. Rainfall and land management effects on erosion and soil properties in traditional Brazilian tobacco plantations. Hydrological Sciences Journal, v. 63, n. 7, p. 1008-1019, 2018. https://doi.org/10.1080/02626667.2018.1472379

BARRETTO, A. G. D. O. P.; LINO, J. S.; SPAROVEK, G. Bibliometrics of Brazilian research on accelerated soil erosion: institutions, themes, space and chronology. Revista Brasileira de Ciência do Solo, v. 33, n. 6, p. 1845-1854, 2009. http://dx.doi.org/10.1590/S0100-06832009000600033

BIALKOWSKI, R.; BUTTLE, J. M. Stemflow and throughfall contributions to soil water recharge under trees with differing branch architectures. Hydrological. Process, v. 29, p. 4068-4082, 2015. https://doi.org/10.1002/hyp.10463

BRECCIAROLI, G. S.; COCCO, A.; AGNELLI, F.; COURCHESNE, G.; CORTI. From rainfall to throughfall in a maritime vineyard. Science of the Total Environment, v. 438, p. 174-188, 2012. https://doi.org/10.1016/j.scitotenv.2012.08.044

BUI, E. N.; BOX, J. R. Stemflow, rain throughfall and erosion under canopies of corn and sorghum. Soil Science Society of America Journal, v. 56, p. 242-247, 1992. https://doi.org/10.2136/sssaj1992.03615995005600010037x

CANONE, D.; PREVIATI, M.; FERRARIS, S. Evaluation of stemflow effects on the spatial distribution of soil moisture using TDR monitoring and an infiltration model. Journal of $\begin{array}{llllll}\text { Irrigation and Drainage Engineering, v.143, n. } & 2017 .\end{array}$ https://doi.org/10.1061/(ASCE)IR.1943-4774.0001120

CZIKOWSKY, M. J.; FITZJARRALD, D. R. Detecting rainfall interception in an Amazonian rain forest with eddy flux measurements. Journal of Hydrology, n. 377, p. 92-105, 2009. https://doi.org/10.1016/j.jhydrol.2009.08.002

DUGAS, W. M. Comparative measurement of stem flow and transpiration in cotton. Theoretical and Applied Climatology, n. 42, v. 4, p. 215-221, 1990. https://doi.org/10.1007/BF00865981

DUNKERLEY, D. Stemflow production and intra storm rainfall intensity variation: an experimental analysis using laboratory rainfall simulation. Earth Surface Processes and Landforms, v. 39, n. 13, p. 1741-1752, 2014. https://doi.org/10.1002/esp.3555

FAN, J. L.; OESTERGAARD, K. T.; GUYOT, A.; LOCKINGTON, D. A. Measuring and modeling rainfall interception losses by a native Banksia woodland and an exotic pine plantation in subtropical coastal Australia. Journal of Hydrology, v. 515, p. 156-165, 2014. https://doi.org/10.1016/j.jhydrol.2014.04.066

FAO. Website. Available at: http://www.fao.org/home/en/. Access: 08 Oct. 2019.

FOLEY, J. A.; DEFRIES, R.; ASNER, G. P.; BARFORD, C.; BONAN, G.; CARPENTER, S. R.; CHAPIN, F. S.; COE, M. T.; DAILY, G. C.; GIBBS, H. K. Global consequences of land use. Science, v. 309, p. 570-574, 2005. https://dx.doi.org/10.1126/science.1111772 
FRASSON, R. P de M.; KRAJEWSKI, W. F. Characterization of the drop-size distribution and velocity-diameter relation of the throughfall under the maize canopy. Agricultural and Forest Meteorology, v. 151, n. 9, p. 1244-1251, 2011. https://doi.org/10.1016/j.agrformet.2011.05.001

GASH, J. An analytical model of rainfall interception by forest. Quarterly Journal of the $\begin{array}{lllllll}\text { Royal Meteorological Society, } & \text { v. } 1979 .\end{array}$ https://doi.org/10.1002/qj.49710544304

GASPAROTO, E. A. G.; TONEllo, K. C.; ShInZATO, E. T.; VAlEnTE, R. D. A. Throughfall in different forest stands of Iperó, São Paulo. CERNE, v. 20, n. 2, p.303309, 2014. http://dx.doi.org/10.1590/01047760.201420021260

GERMER, S. Development of near-surface perched water tables during natural and artificial stemflow generation by babassu palms. Journal of Hydrology, v. 507, p. 262-272, 2013. https://doi.org/10.1016/j.jhydrol.2013.10.026

HERWITZ, S. R. Interception storage capacities of tropical rainforest canopy trees. Journal of Hydrology, v.77, p. 237-25, 1985. https://doi.org/10.1016/0022-1694(85)90209-4

HORNBUCKLE, J. W.; GOODWIN, I.; CHRISTEN, E. W.; ZANDONA, R. Development of a real time spatial assessment tool for grapevine canopy vigour and water stress. Acta $\begin{array}{llllll}\text { Horticulturae, } & \text { v. } & 792, & \text { p. } & 355-361 . & 2008 .\end{array}$ https://doi.org/10.17660/ActaHortic.2008.792.41

LEVIA JR., D. F.; FROST, E. E. Variability of throughfall volume and solute inputs in wooded ecosystems. Progress in Physical Geography: Earth and Environment, v. 30, p. 605632, 2006. https://doi.org/10.1177\%2F0309133306071145

LEVIA JR., D. F.; FROST, E. E. A review and evaluation of stemflow literature in the hydrologic and biogeochemical cycles of forested and agricultural ecosystems. Journal of Hydrology, v. 274, p.1-29, 2003. https://doi.org/10.1016/S0022-1694(02)00399-2

LEVIA, D. F.; GERMER, S. A review of stemflow generation dynamics and stemflowenvironment interactions in forests and shrublands. Reviews of Geophysics, v. 53, p. 673-714, 2015. https://doi.org/10.1002/2015RG000479

LIANG, W. L.; KOSUGI, K.; MIZUYAMA, T. Soil water dynamics around a tree on a hillslope with or without rainwater supplied by stemflow. Water Resources Research, v. 47, p. 1-16, 2011. https://doi.org/10.1029/2010WR009856

MALHI, Y.; ROBERTS, J. T.; BETTS, R. A.; KILLEEN, T. J.; LI, W.; NOBRE, C. A. Climate change, deforestation, and the fate of the Amazon. Science, v. 319, p. 169-172, 2008. https://dx.doi.org/10.1126/science.1146961

MARENGO, J. A.; ESPINOZA, J. C. Extreme seasonal droughts and floods in Amazonia: causes, trends and impacts. International Journal of Climatology, v. 36, p.1033-1050, 2016. https://doi.org/10.1002/joc. 4420

PACHAURI, R. K.; ALLEN, M. R.; BARROS, V. R.; BROOME, J.; CRAMER, W.; CHRIST, R.; CHURCH, J. A.; CLARKE, L.; DAHE, Q.; DASGUPTA, P. Climate change 2014: synthesis report. Contribution of Working Groups I, II and III to the fifth assessment report of the Intergovernmental Panel on Climate Change, Ipcc. Geneva, 2014. 
PBMC. First National Assessment Report of the Brazilian Panel on Climate Change. Impacts, Vulnerabilities and Adaptation. Executive Summary of GT2. Rio de Janeiro, 2013.

RANALLI, A. J.; MACALADY, D. L. The importance of the riparian zone and in-stream processes in nitrate attenuation in undisturbed and agricultural watersheds - A review of the scientific literature. Journal of Hydrology, v. 389, n. 3-4, p. 406-415, 2010. https://doi.org/10.1016/j.jhydrol.2010.05.045

RUTTER, A.; KERSHAW, K.; ROBINS, P.; MORTON, A. A predictive model of rainfall interception in forest. I. Derivation of the model from observation in a plantation of Corsican pine. Agricultural Meteorology, v. 9, p. 367-384, 1971. https://doi.org/10.1016/0002-1571(71)90034-3

SOUSA JR., S. F de.; MENDES, T. A.; SIQUEIRA, E. Q de. Development and calibration of a rainfall simulator for hydrological studies. RBRH, v. 22, p. 45 -59, 2017. https://doi.org/10.1590/2318-0331.0217170015

STEINER, J. L.; KANEMASU, E. T.; CLARK, R. N. Spray losses and partitioning of water under a center pivot sprinkler system. Transactions of the ASAE, v. 26, n. 4, p. 11281134, 1983.

TOBÓN MARIN, C.; BOUTEN, W.; SEVINK. J. Gross rainfall and its partitioning into throughfall, stemflow and evaporation of intercepted water in four forest ecosystems in western Amazonia. Journal of Hydrology, v. 23, n. 7, p. 40-57, 2000. https://doi.org/10.1016/S0022-1694(00)00301-2

TOGASHI, H. F.; MONTEZUMA, R. de C. M.; LEITE, A. F. Gross rainfall and throughfall in three secondary succession gradients of atlantic rain forest on Pedra Branca massif, Rio de Janeiro. Revista Árvore, v. 36, n. 5, p. 907-918, 2012. https://doi.org/10.1590/S010067622012000500013

VAN STAN, J. T.; GORDON, D. A. Mini-Review: Stemflow as a Resource Limitation to NearStem Soils. Frontiers in Plant Science, v. 9, p. 1-7, 2018. https://doi.org/10.3389/fpls.2018.00248

YUAN, C.; GAO, G.; FU, B. Stemflow of a xerophytic shrub (Salix psammophila) in northern China: Implication for beneficial branch architecture to produce stemflow. Journal of Hydrology, v. 539, p. 577-588, 2016. https://doi.org/10.1016/j.jhydrol.2016.05.055

ZHANG, Y. F.; WANG, X. P.; PAN, R.; YAN-XIA, H. Stemflow volume per unit rainfall as a good variable to determine the relationship between stemflow amount and morphological metrics of shrubs. Journal of Arid Environments, v.141, p.1-6, 2017. https://doi.org/10.1016/j.jaridenv.2017.02.002

ZHAO, L.; FANG, Q.; TANG, Y.; YANG, H.; YANG, T.; ZHENG, H. Stemflow contributions to soil erosion around the stem base under simulated maize-planted and rainfall conditions Agricultural and Forest Meteorology, v. 281, n. 107814, 2020. https://doi.org/10.1016/j.agrformet.2019.107814

ZHENG, J.; JUNLIANG, F.; ZHANG, F.; YANA, S.; WUA, Y.; J LUA, J.; GUO, J.; CHENG, M.; PEIC, Y. Throughfall and stemflow heterogeneity under the maize canopy and its effect on soil water distribution at the row scale. Science of the Total Environment, v. 660, p.1367-1382. 2019. https://doi.org/10.1016/j.scitotenv.2019.01.104 